\title{
Studies on the Production of the Montecristo Banana Grown on the South Coast of Puerto Rico
}

\author{
F. Sánchez Nieva, G. Colom Covas, I. Hernández, \\ C. Bueso de Viñas and R. Guadalupe
}

\section{INTRODUCTION}

Bananas have never been produced in Puerto Rico in a well-organized way. The fruit is grown in coffee farms as a secondary cash crop, which at the same time provides shade for the coffee trees. No organized method of harvesting is followed, the fruit being generally harvested by visual inspection, the farmer himself judging the best time for harvesting. The fruit delivered to ripening plants sometimes does not have uniform ripening characteristics, which, in turn, results in ripened fruit of poor quality. The Montecristo banana (Cavendish subgroup of Eumusa) is the type of fruit generally planted.

With the development of modern marketing systems in which supermarkets handle a large volume of the fresh produce sales, there is need to improve the quality of bananas to meet the requirements of a more demanding consumer. Furthermore, with the rapid development of the food-processing industry, there is a strong possibility of processing bananas in the near future.

In order to supply the fruit to the fresh market and to processing plants, it is desirable to develop the production of bananas in a more formal way, applying the techniques used in banana-producing countries to cultivate and harvest the fruit. As a first step to achieve this goal, the Montecristo cultivar grown in the Island must be characterized.

This paper describes the results of preliminary studies, conducted to determine the effect of the time of planting and shooting on the development of the fruit and on the yields, the proper stage for harvesting, ripening characteristics and quality of the fruit. For these studies, no efforts were made to select any specific clone. Rather, the planting material was selected at random from a banana-producing farm, so that the experimental plots would be representative samples of typical commercial plantations with the normal variation in clonal characteristics. In this way, the bananas as grown

1 Technical Director, Associate Horticulturist, Assistant Chemical Engineer, and Research Assistants, respectively, Food Technology Laboratory, Agricultural Experiment Station, Mayagüez Campus, University of Puerto Rico, Río Piedras, P.R. The authors wish to express their gratitude to the staff of the Fortuna Substation for the assistance given in the field experiment, and to Miss Noemi Diaz, former Research Assistant at the Food Technology Laboratory, for conducting some of the analytical work used in this study. 
by farmers are characterized and the results of this work may be directly applicable to commercial production under existing conditions.

Since the study was directed primarily to obtain data on the behavior and general characteristics of the Montecristo cultivar, the Fortuna Substation on the South Coast was selected to establish the experimental plots. Being at sea level, with fairly uniform climate and with irrigation, this area provided better conditions for these studies than the mountainous area where bananas are produced.

\section{REVIEW OF THE LITERATURE}

Bananas have been extensively studied. The literature available on the history, classification of the cultivars, cultivation, harvesting, transportation, storage, and ripening is extensive. Excellent reviews and treatises on the subject are available such as the works of Kervegant $(1)^{2}$ von Loesecke (2), Cardeñosa (3), Simmonds (4), and Champion (5). Manuals on ripening treatments with recommendations of fruit handling and ripening are also available $(6)$.

Bananas for export are usually harvested about 80 to 95 days after shooting. Climatic conditions have an effect on the interval from time of shooting to harvesting. According to Champion (5), during cold weather the fruit may require as much as 180 days for development. The stage for cutting depends also on clonal characteristics (4).

Wardlow et al. (7) studied the development of the Gros Michel fruit under tropical conditions. Pulp and peel weights, fruit weights and biochemical changes were studied during the period of development to the stage of incipient ripeness on the plant. The weight of the fingers and of the pulp were found to increase for the entire period of development. The pulp:peel ratio was found to increase almost linearly. During development, sugars remained at a low concentration while starch increased rapidly. When the stage of incipient ripeness was approached, the starch content decreased and the sugars increased. The carbohydrate content of the different grades could not be specifically related to maturity. The percentage of dry matter also increased during the development period. Acidity was observed to decrease during the accumulation of starch and to increase when the starch hydrolysis started.

Simmonds reviewed the effect of unfavorable weather on bananas (4). In subtropical latitudes, vegetative growth is reduced in winter and bunches develop slowly. Shooting is also delayed. The time for shooting may be delayed in the Tropies by high altitude. Weather variations are responsible for the periodicity of production generally observed throughout the year.

Few studies on bananas have been conducted in Puerto Rico. González

2 Italic numbers in parentheses refer to Literature Cited, p. 306. 
Ríos (8) reported on the cultivation of bananas in Puerto Rico and described the principal clones found on the Island. The effect of shade on the yields of bananas grown on the Humid Mountain Region of Puerto Rico was studied by Vicente $e t$ al. (9). Yields twice as high of marketable fruit were produced under shade than in full sunlight when no control for the Sigatoka leaf spot disease (Cercospora musae) was practiced. The control of the leaf spot disease by spray oil schedules based on rainfall data was studied by Calpouzos et al. (10).

TABLE 1.-Planting and shooting dales and characteristics of the flowering period for the 18 plots

\begin{tabular}{|c|c|c|c|c|c|c|}
\hline \multirow{2}{*}{ Plot No. } & \multirow{2}{*}{ Planting date } & \multirow{2}{*}{$\begin{array}{l}\text { Date of first } \\
\text { inflorescence }\end{array}$} & \multicolumn{3}{|c|}{$\begin{array}{l}\text { Interval from planting } \\
\text { to shooting }\end{array}$} & \multirow{2}{*}{$\begin{array}{c}\text { Difiference } \\
\text { in days } \\
\text { between } \\
\text { earlienst } \\
\text { and } \\
\text { latest } \\
\text { fowering } \\
\text { plants }\end{array}$} \\
\hline & & & Range & Mean & $\begin{array}{l}\text { Stand- } \\
\text { ard } \\
\text { devia- } \\
\text { tion }\end{array}$ & \\
\hline & & & Days & Days & Days & Days \\
\hline 1 & Oct. 9,1963 & Sept. 24,1964 & $350-480$ & 400 & 28 & 130 \\
\hline 2 & Nov. 7,1963 & Oct. 7,1964 & $334-451$ & 394 & 29 & 117 \\
\hline 3 & Dec. 23,1963 & Nov. 5, 1964 & $317-419$ & 371 & 25 & 102 \\
\hline 4 & Jan. 24, 1964 & Nov. 10,1964 & $290-437$ & 353 & 10 & 147 \\
\hline 5 & Feb. 28, 1964 & Jan. 1, 1965 & $307-437$ & 374 & 30 & 120 \\
\hline 6 & March 26, 1964 & Feb. 5, 1965 & $306-424$ & 376 & 31 & 114 \\
\hline 7 & April 9, 1964 & Feb. 22, 1965 & $319-445$ & 388 & 12 & 126 \\
\hline 8 & May 26, 1964 & Feb. 11, 1965 & $261-398$ & 319 & 26 & 137 \\
\hline 9 & June 25,1964 & April 30, 1965 & $309-420$ & 353 & 27 & 111 \\
\hline 10 & July 29,1964 & June 3,1965 & $308-421$ & 354 & 25 & 113 \\
\hline 11 & Aug. 31, 1964 & June 26,1965 & $299-441$ & 356 & 28 & 142 \\
\hline 12 & Sept. 29,1964 & Aug. 10,1965 & $315-419$ & 359 & 20 & 104 \\
\hline
\end{tabular}

\section{EXPERIMENTAL PROCEDURES}

Monthly plantings of 100 plants each were established under full sunlight at the Fortuna Substation on the South Coast of Puerto Rico at the dates indicated in table I. The planting material, of the cultivar known in Puerto Rico as Montecristo Grande, was obtained from the Castañer farm in the Adjuntas Region. The seeds (pseudo-rhizomes) were chosen to be of similar size and weight, and were planted at a distance of 10 feet $\times 10$ feet. The corms were peeled and dipped in a 2.5-percent solution of Aldrin to control the borer Cosmopolites sordidus $\mathrm{G}$. The planting holes were also treated with the same solution, and the plots were sprayed 180 days after planting. Fertilizer formula 12-6-10 was applied according to the following schedule: 1 pound 60 days after planting and 1 pound every 60 days until 
the third application. A fourth application was given 60 days later, or at the time of shooting, if this happened before the fertilizer application was due.

To control the leaf spot disease, the plants were sprayed with OrchardSpray Oil every 15 days at the rate of 3 to 4 liters per cuerda. ${ }^{3}$ Weeds were removed as needed. No shoots were allowed to grow until shooting. The plots were irrigated once a week by flooding the furrows.

Dates of shooting were recorded. Bunches were harvested at predetermined ages measured from time of shooting. The bunches were transported to the Laboratory wrapped in padded cotton mats to avoid bruising. The bunches were weighed with the stem attached, but with both the male bud and its stem cut off close to the last hand. The hands and fingers were counted. Fingers from the second hand were sampled for chemical analyses and to determine the weights of pulp and peel. Pulp:peel ratios were calculated from average weights of pulp and peel.

To study the changes taking place during the development of the fruit, several bunches were randomly selected and left on the tree until incipient ripeness was observed. At regular intervals, fingers were removed from the second hand without disturbing or damaging neighboring fingers. The wound was immediately covered with hot paraffin. The weights of the fruit, pulp, and peel were determined. Sugars and starch, pH and acidity, and the moisture content were determined in the pulp. Results were expressed on a pulp fresh-weight basis.

To determine the ripening characteristics, the bunches were left overnight at room temperature and placed in the ripening room next morning. The temperature of the ripening room was adjusted to $68^{\circ} \mathrm{F}$. with a relative humidity of 95 to 100 percent. After 1 day in the ripening room, ethylene was applied at the rate of 1 cubic foot per 1,000 cubic feet of room space. A second ethylene dosage was applied about 7 to 8 hours later. Following the ethylene application, the room was ventilated with an exhaust fan through a bunk door for 15 minutes every 24 hours. After turning, the temperature was lowered to $66^{\circ} \mathrm{F}$. until the fruit reached a peel color of 4 to 5, according to the color chart published by the Fruit Dispatch Co. (6). The average weights of fingers from all hands were recorded. Fingers from the second hand were removed for chemical analyses. All analyses were run on the pulp and the results expressed in terms of the fresh-pulp weight.

Starch was determined by the method of Carter and Neubert (11). Sugars were determined by the method of Moyer and Holgate (12). Acidity, $\mathrm{pH}$, and moisture were measured by A.O.A.C. procedures (19).

31 cuerda $=0.9712$ acre. 


\section{RESULTS AND DISCUSSION}

\section{EFFECT OF THE TIME OF PLANTING ON THE FLOWERING}

\section{AND PRODUCTION PATTERNS}

The experiment lasted from October 1963, when the first plot was planted, to January 1966, when the last bunches were harvested. This period was characterized by an extreme drought, with a rainfall of less than 2 inches per month 13 months out of the total of 27 for the whole experiment. The temperature and rainfall data for the period from planting to harvesting are plotted in figure 1. It should be noted that flowering started during September 1964, when the maximum rainfall was recorded.

The flowering characteristics of the 12 plots are shown in table 1. Plots

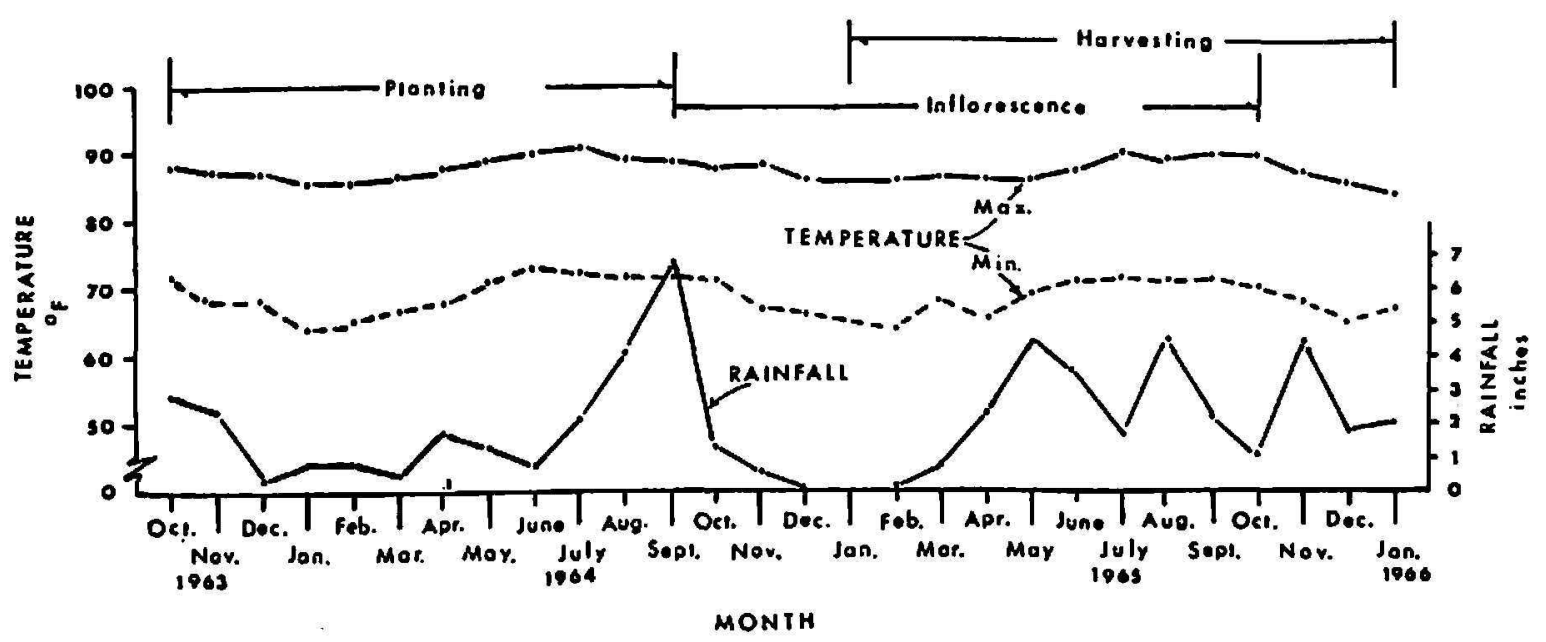

FIG. 1.-Temperature and rainfall data for the period from planting to harvesting.

No. 1 to 4 started to bloom within a period of 47 days. Plot No. 5 bloomed 52 days later than plot No. 4. Plots Nos. 5, 6, 7, and 8 bloomed within a period of 41 days. Plot No. 9 bloomed 78 days later than Plot No. 8 ; No. 10, 34 days later than No. 9; No. 11, 23 days later than No. 10; and No. 12,45 days later than No. 11. Since the flowering span in all plots ranged from 102 to 147 days, planting every month resulted in continuous blooming throughout the year.

The percentage distribution of plants flowering at 10-day intervals for the 12 plots combined is shown in figure 2 . This distribution indicates three alternate periods of low and high percentage of plants flowering as a result of the grouping of the plots into definite periods of flowering. The general shape of the frequency distribution curve approaches that of a normal distribution.

Figure 3 shows the frequency distribution in terms of the percentage of plants flowering at 10-day intervals for plots Nos. 1,2,3, and 4. The curves are displaced from each other by the corresponding interval in days be- 
tween the first inflorescence of consecutive plots. Plots Nos. 1 and 2 exhibited similar frequency distributions and with a similar flowering span, the period of flowering and fruit production almost coincided. Plots Nos. 3 and 4 bloomed within a period of 5 days, and therefore, their periods of flowering and fruit production also coincided.

Similar frequency distributions for plots Nos. 5, 6, 7, and 8 are shown in figure 4. The flowering periods of plots No. 5 and No. 6 coincided. Similarly the flowering period of plot No. 7 almost coincided with that of No. 8 .

The frequency distributions for plots Nos. 9, 10, 11, and 12 are shown in figure 5. Since the interval between blooming of consecutive plots ranged

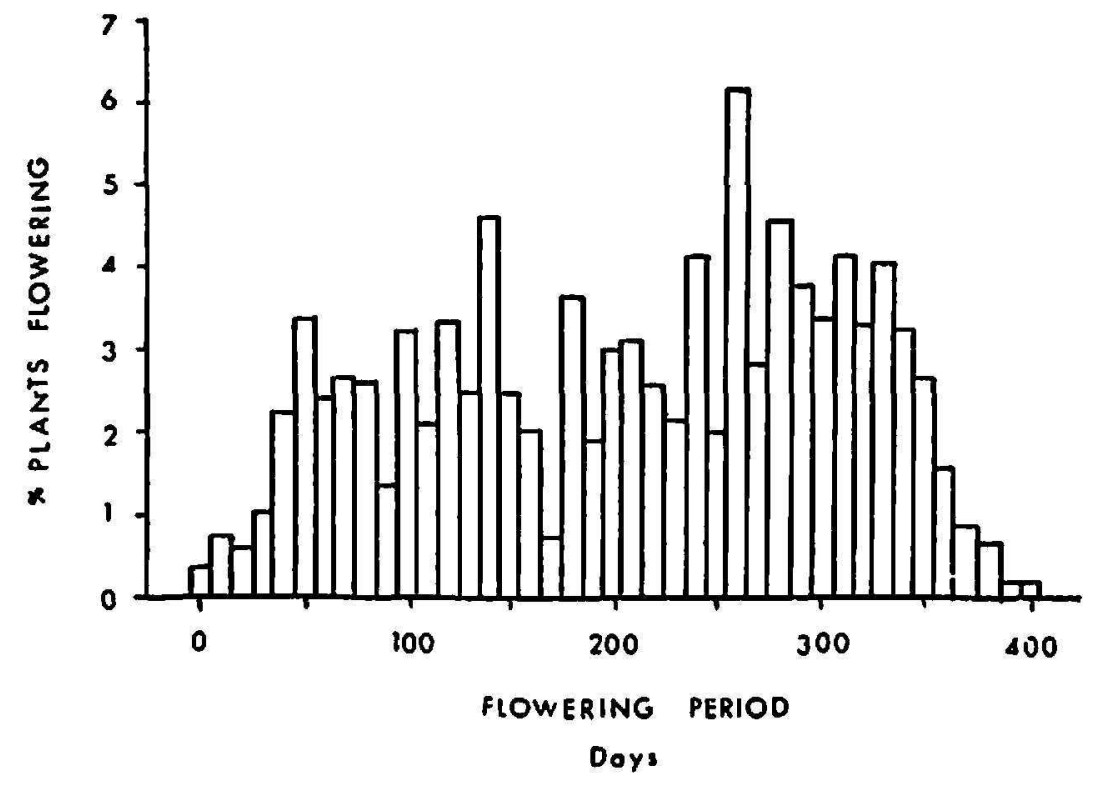

Fig. 2.-Percentage distribution of plants flowering in all 12 plots throughout the study.

from 34 to 45 days, each plot stands by itself and each had its production peak displaced from each other.

Because of the grouping of the plots as indicated, it appears that uniform fruit production throughout the year would have been obtained also by planting every other month until the ninth plot, followed by monthly plantings for the remaining three. If the frequency distribution of the percentage of plants flowering in alternate plots until the ninth, as indicated, and in consecutive plots from the 9 th to the 12 th is calculated, the curve in figure 6 is obtained. When this frequency distribution is compared with that of figure 2 , it is noted that monthly plantings resulted in a more uniform production pattern throughout the year. This is because, although some of the plots bloomed within a short interval of time, since the flowering distribution of all plots exhibited an almost normal distribution pattern, dis- 
placement of the peaks of maximum production smoothes the frequency distribution curve for the 12 plots combined.

To stidy the effect of the time of planting on the several attributes determining the quality of the fruit,' two approaches are possible: One alternative is to relate the quality attributes to the time of planting; the second

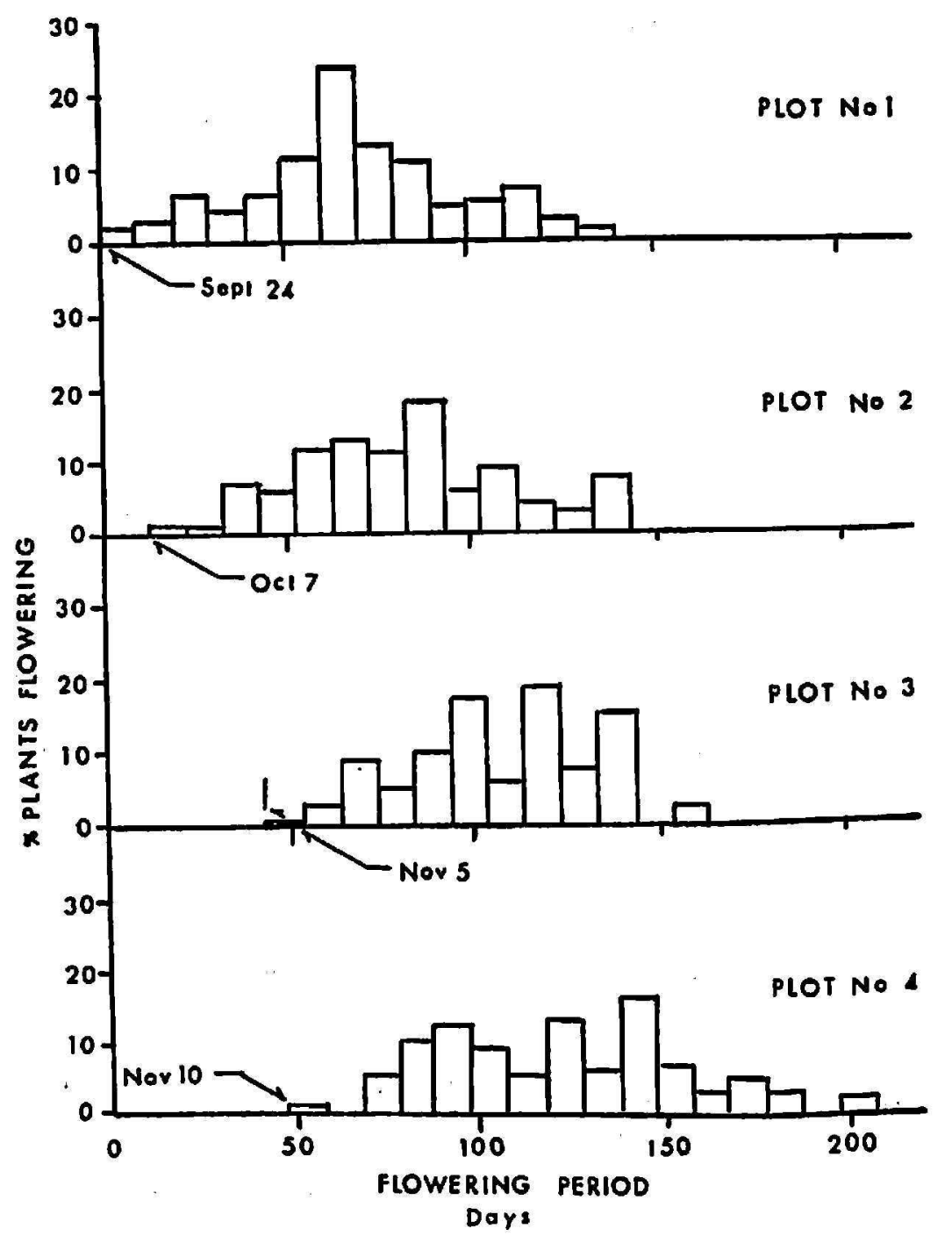

Fre. 3.-Frequency distribution for plants flowering in plots Nos. 1, 2, 3, and 4.

alternative is to study the variations in quality in relation to the time of the year in which inflorescence occurred.

It has been shown that monthly plantings resulted in continuous inflorescence throughout the year, with the flowering span for each plot exceeding a period of 3 months. The time of planting had a direct effect on the time at which the plots started to bloom, as a result of which a grouping of the plots into definite periods of inflorescence was observed. Because of the long flowering span of the individual plots, at any time of the year, 
fruits from several plots will be harvested. Consequently, it seems more convenient to study the variations in the quality attributes as related to specific periods of inflorescence, rather than on the basis of planting dates. In this way all bunches produced from plants blooming within a definite period can be studied.

In order to relate the changes in the quality attributes studied with the time of planting and the period of harvesting, the reader is referred to the following tabulation in which the interrelation of planting, shooting and harvesting dates are indicated.

\begin{tabular}{|c|c|c|c|}
\hline Plot No. & Date of planting & Dates of shooting & Dates of harvesting \\
\hline 1,2 & $\begin{array}{l}\text { October } 1963 \\
\text { November } 1963\end{array}$ & $\begin{array}{l}\text { September } 1964 \text { to February } \\
1965\end{array}$ & January to May 1965 \\
\hline 3,4 & $\begin{array}{l}\text { December } 1963 \\
\text { January } 1864\end{array}$ & November 1964 to April 1965 & February to July 1965 \\
\hline 5,6 & $\begin{array}{l}\text { February } 1964 \\
\text { March } 1964\end{array}$ & January to May 1965 & April to September 1965 \\
\hline 7,8 & $\begin{array}{l}\text { April } 1964 \\
\text { May } 1964\end{array}$ & February to June 1965 & June to October 1965 \\
\hline $\begin{array}{r}9 \\
10\end{array}$ & $\begin{array}{l}\text { June } 1964 \\
\text { July } 1964\end{array}$ & $\begin{array}{l}\text { April to August } 1965 \\
\text { June to October } 1965\end{array}$ & $\begin{array}{l}\text { August to December } 1965 \\
\text { September } 1965 \text { to January } \\
\text { log6 }\end{array}$ \\
\hline 11 & August 1964 & June to November 1965 & $\begin{array}{l}\text { October } 1965 \text { to February } \\
1966\end{array}$ \\
\hline 12 & September 1964 & August to December 1965 & $\begin{array}{l}\text { November } 1965 \text { to March } \\
1966\end{array}$ \\
\hline
\end{tabular}

\section{EFFECT OF THE TIME OF SHOOTING ON THE DEVBLOPMENT OF THE FRUIT}

To set guidelines to study the effect of the time of shooting on the development of the fruit of the Montecristo cultivar, preliminary experiments were conducted in which a fruit from the second hand of several bunches were cut at frequent intervals during the development period until the stage of incipient ripeness. The weights of fruit, pulp and peel were measured in this way from the same bunch at different stages of development. The starch and sugar content, $\mathrm{pH}$, acidity, and moisture were determined on the pulp of the fruit.

The data from two of the bunches studied are given in table 2. The curves on figures 7 and 8 show that the weight of the fruit increased with age until incipient ripeness, the increase in weight being almost linear during the last stages of development. The pulp content increased steadily with age, but showed a trend to level-off by the time the fruit started to ripen.

Figure 9 shows the variation of pulp: peel ratio during development. From an age range of 68 to 125 days, the change in the pulp:peel ratio is linear. 
The test for goodness of fit of the sample regression equation gave a calculated " $t$ " value of $\mathbf{1 4 . 7 5}$ which is highly significant.

Since the fruit reaches full development at the time of incipient ripeness, the stage of development of the fruit at the time it was harvested was determined by dividing the pulp content at different age intervals by the

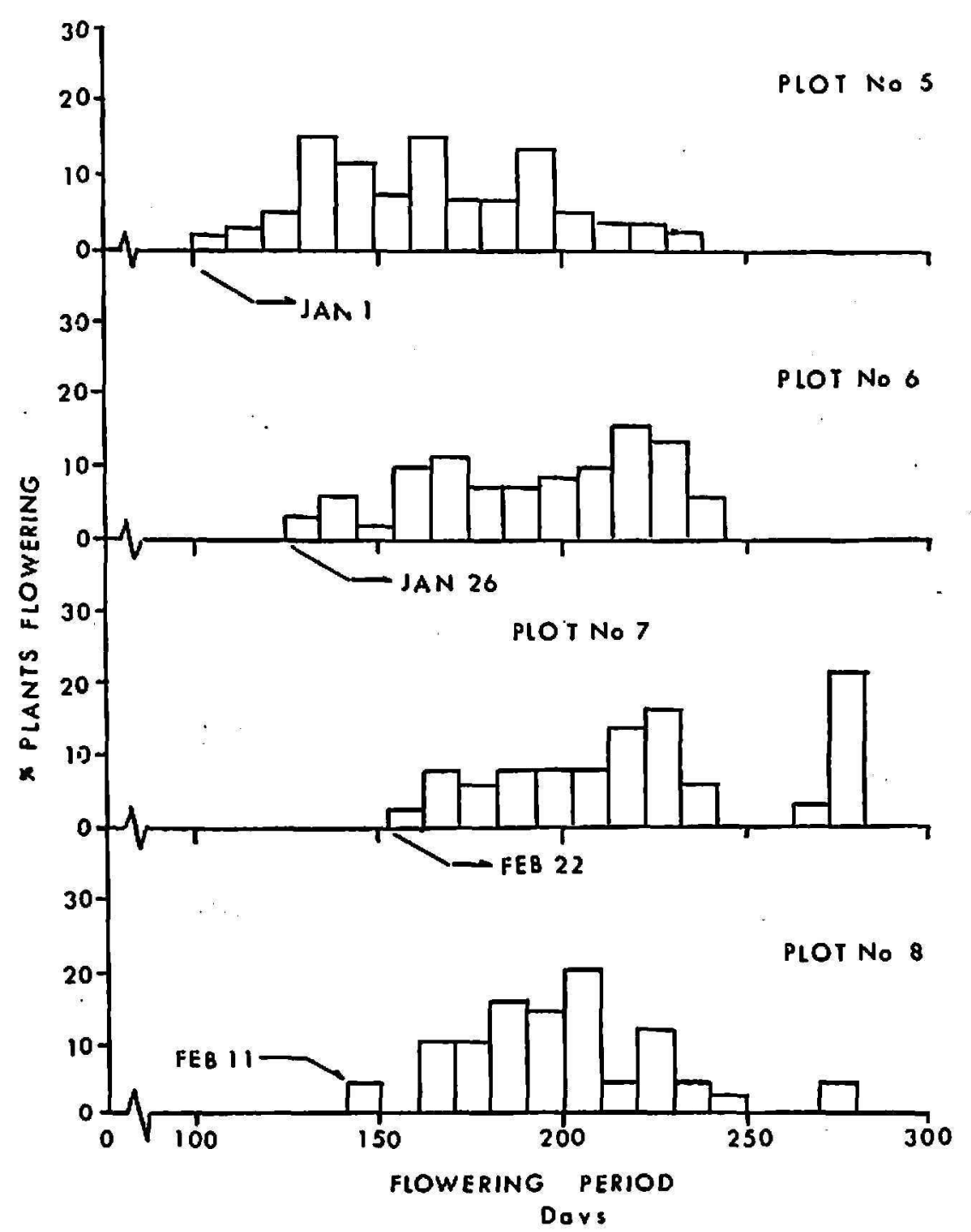

Frg. 4.-Frequency distribution for plants flowering in plots Nos. 5, 6, 7, and 8.

pulp content at incipient ripeness. The stage of development is indicated in table 2 as "percent development".

The changes observed in the chemical composition of the fruit during development follows the same trend of the data obtained by Wardlaw et $a l .(7)$ in the Gros Michel fruit. The starch reached its maximum value just before the fruit started to ripen after which the starch content decreased. The loss in starch exceeded the increase observed in the sugar content. Wardlaw suggested that the loss of the starch which cannot be accounted for by the increase in the sugars may be due to the loss of carbon 


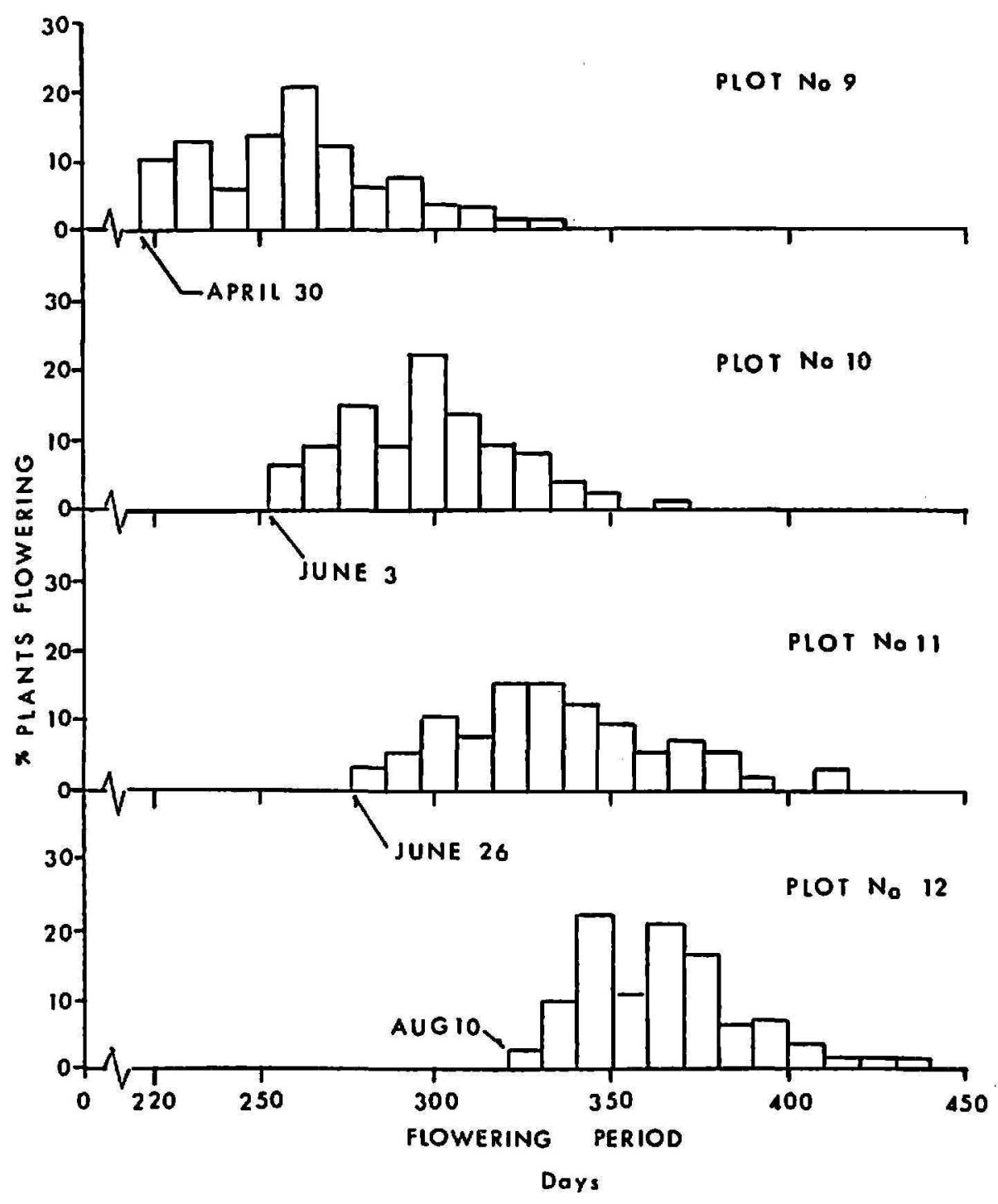

Fra. 5.-Frequency distribution for plants flowering in plots Nos. 9, 10, 11, and 12.

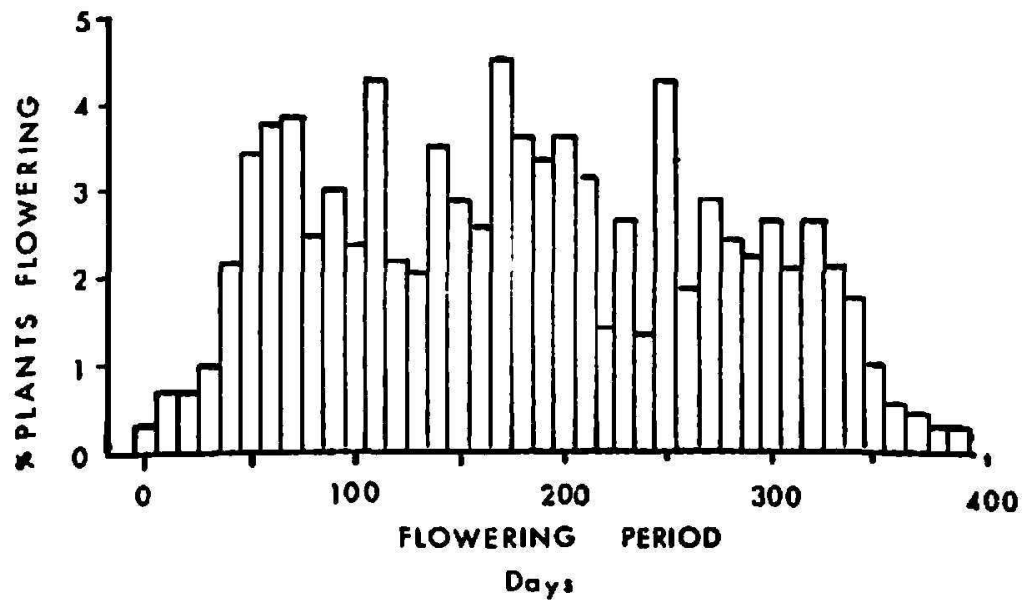

Fra. 6.-Percentage distribution of plants flowering from plots Nos. 1, 3, 5, 7, 9, 10,11 , and 12 . 
TABLE 2.-Changes in the physical and chemical properties of the fruit during development

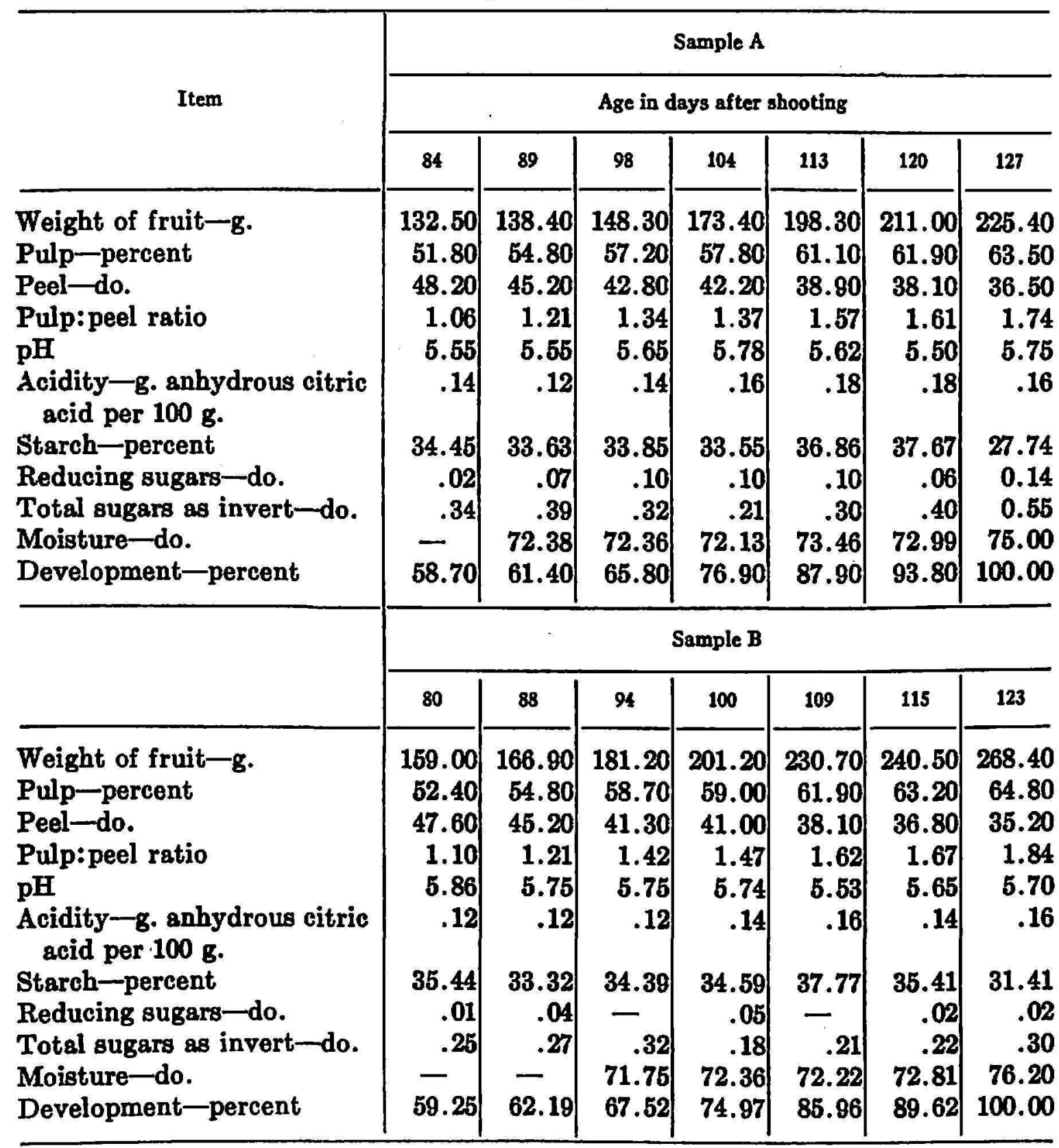

through respiration. The reducing sugars and sucrose values obtained in this study are similar to the values reported by Wardlaw. However, the starch content of the pulp of the Gros Michel fruit studied bv Wardlaw was around 16 percent, while the starch content of the Montecristo fruit at a comparable stage of development was about 34 to 37 percent.

During the period of development studied, in which the first samples were taken at near the "three-quarter stage", a slight increase in total acidity 'was observed, but there was no change in $\mathrm{pH}$. The percentage of mois- 


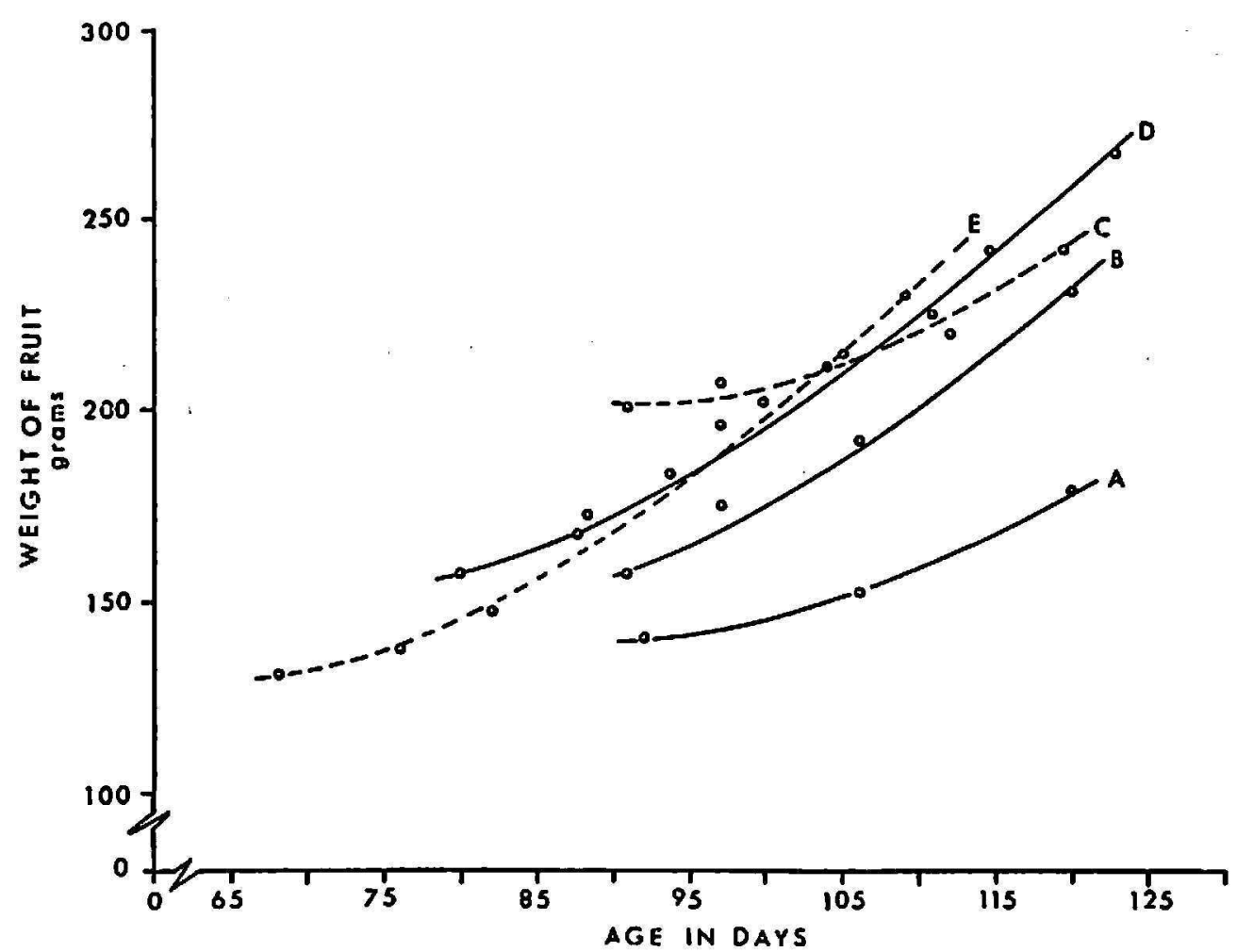

Fra. 7.-Increase in the weight of the fruit during the development of 5 bunches.

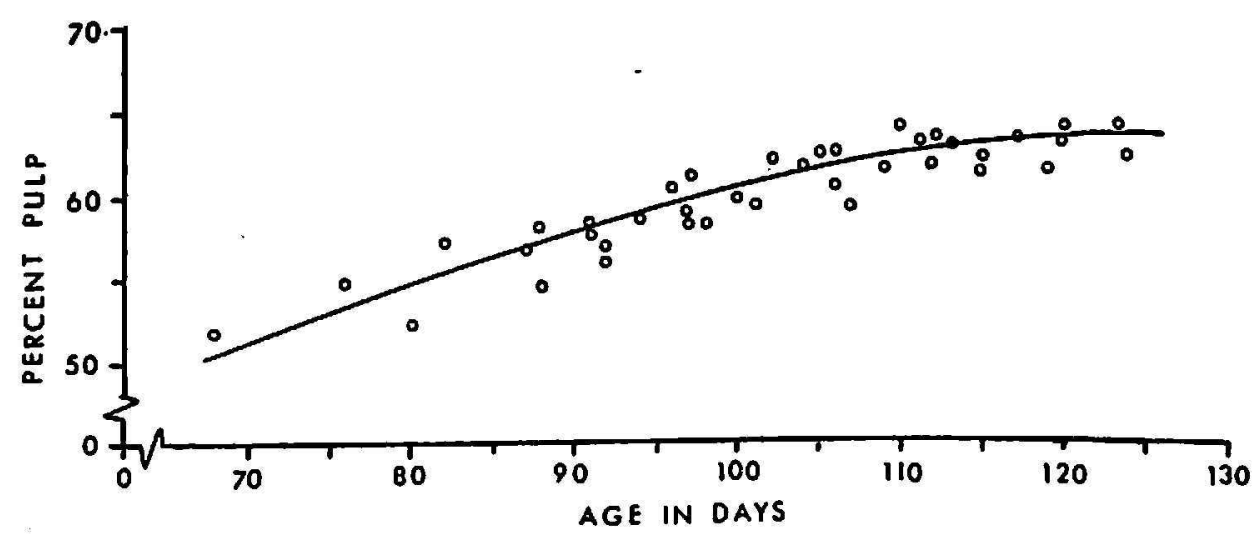

FiG. 8.-Variation in the pulp content during the development of the fruit of 5 bunches.

ture in the pulp increased gradually during development. A more abrupt increase in the moisture content was observed when the fruit started to turn.

In general terms, it can be concluded that the Montecristo fruit followed the same course of development as that observed by Wardlaw in the Gros Michel fruit.

Based on data obtained from a large number of bunches harvested, the following classification was used to grade the bananas. It is based on the commercial grades $(6)$ judged from the appearance of the fruit and the plumpness of the fingers. 
Pulp:peel

Grade

Percent develop- $\quad<70$ ment
1.20

Three-quarter
$1.20-1.40$

Light full three- Full three-quarter quarter

70-80

$80-90$

Not all the bunches harvested were within this classification, since it is well known in the banana trade that the plumpness of the fingers cannot always be related to the stage of development or the age. This classifica-

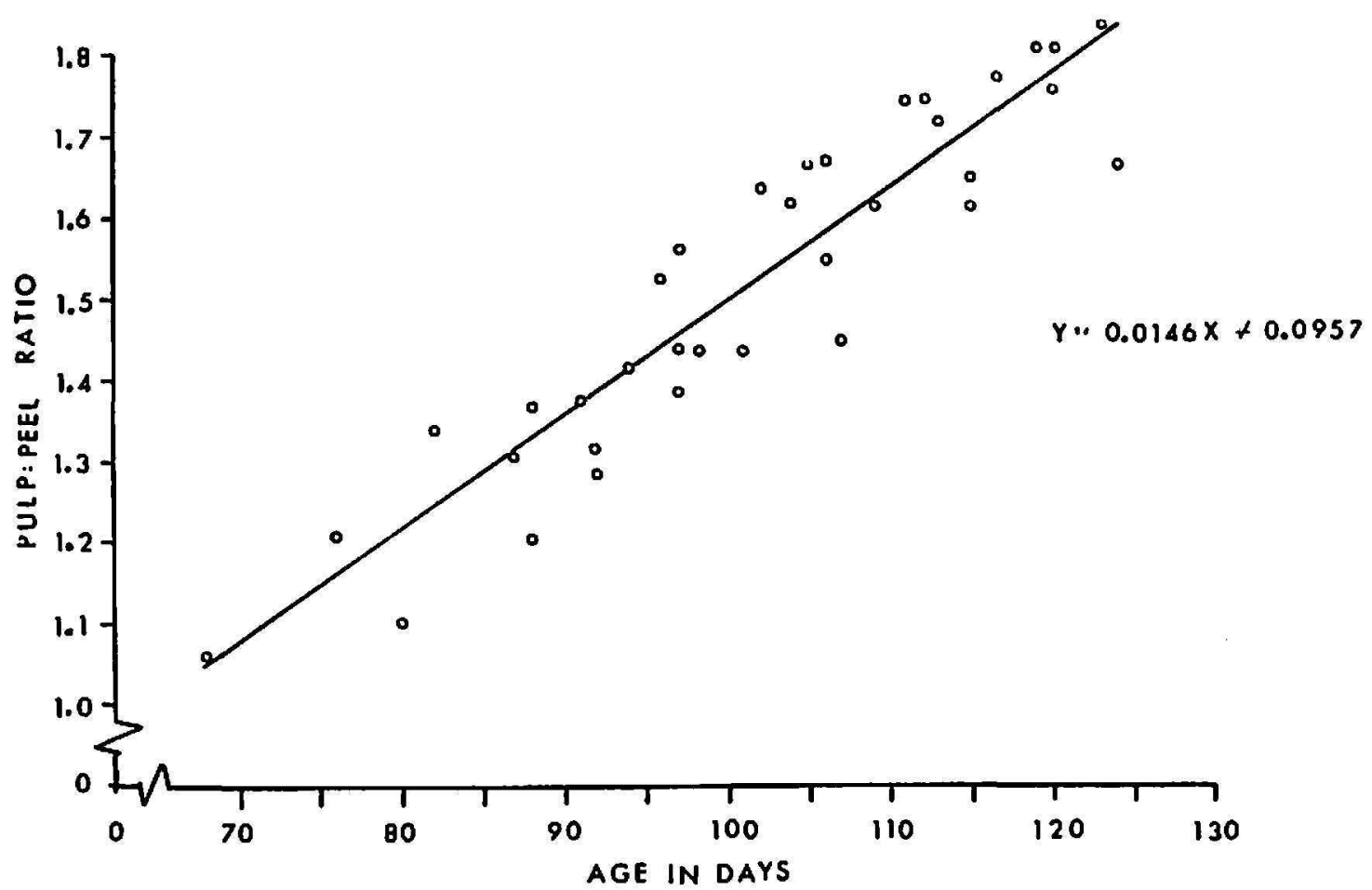

Fra. 9.-Variation in the values of the pulp:peel ratio during the development of the fruit.

tion, however, proved useful to grade the bananas when studying the effect of time of shooting on the stage of development at harvesting.

Bunches were harvested at different ages throughout the year and the pulp:peel ratio was measured from fruits taken from the second hand. The bunches were grouped according to the range of values for the pulp:peel ratios shown in table 3 . The average age for each group was determined for each month of flowering. Figure 10 shows the variation in age with the month of flowering for three groups of bunches with pulp:peel ratio in the ranges of 1.40-1.49, 1.50-1.59 and 1.60-1.69. All three curves show the same trend, indicating a direct effect of the time of flowering on the age at which the fruit reached a definite stage of development. The effect of the time of inflorescence on the age of the bunch, or the stage of development, is best seen by following the curve for a pulp: peel ratio of 1.50-1.59. For this stage 
TABLE 3.-Relation of age and pulp:peel ratio for bunches harvested every calendar month throughout the year

\begin{tabular}{l|c|c|r|r|r|r|c}
\hline \multirow{2}{*}{$\begin{array}{l}\text { Month of } \\
\text { flowering }\end{array}$} & \multicolumn{7}{|c}{ Pulp:peel ratio } \\
\cline { 2 - 7 } \multicolumn{1}{c|}{1964} & $1.10-1.19$ & $1.20-1.29$ & $1.30-1.39$ & $1.40-1.49$ & $1.50-1.59$ & $1.60-1.69$ & $1.70-1.79$ \\
October & & & & & & & \\
November & - & 98.0 & 102.0 & 100.0 & 110.5 & - & - \\
December & 99.0 & 102.0 & 105.8 & 106.0 & 111.0 & 110.5 & 113.0 \\
$\quad 1965$ & & & & & & & \\
January & - & 108.0 & 103.0 & 104.5 & 122.0 & 114.0 & 130.5 \\
February & - & 99.0 & 105.7 & 108.0 & 111.0 & 115.0 & 119.0 \\
March & - & - & 93.0 & - & 109.0 & 113.5 & - \\
April & - & - & - & 104.5 & 101.0 & - & - \\
May & 107.0 & 106.5 & 101.8 & 99.6 & 105.0 & 109.0 & 102.0 \\
June & - & 97.0 & 99.6 & 100.0 & 102.0 & 103.0 & 102.0 \\
July & - & 90.0 & 98.8 & 97.3 & 96.8 & 100.5 & 97.5 \\
August & 99.0 & 106.0 & 98.2 & 99.5 & 102.9 & 104.4 & 105.3 \\
September & 96.0 & 98.5 & 100.3 & 102.6 & 108.7 & 117.0 & - \\
October & 96.0 & 99.7 & 104.0 & 99.6 & 102.0 & - & - \\
\hline
\end{tabular}

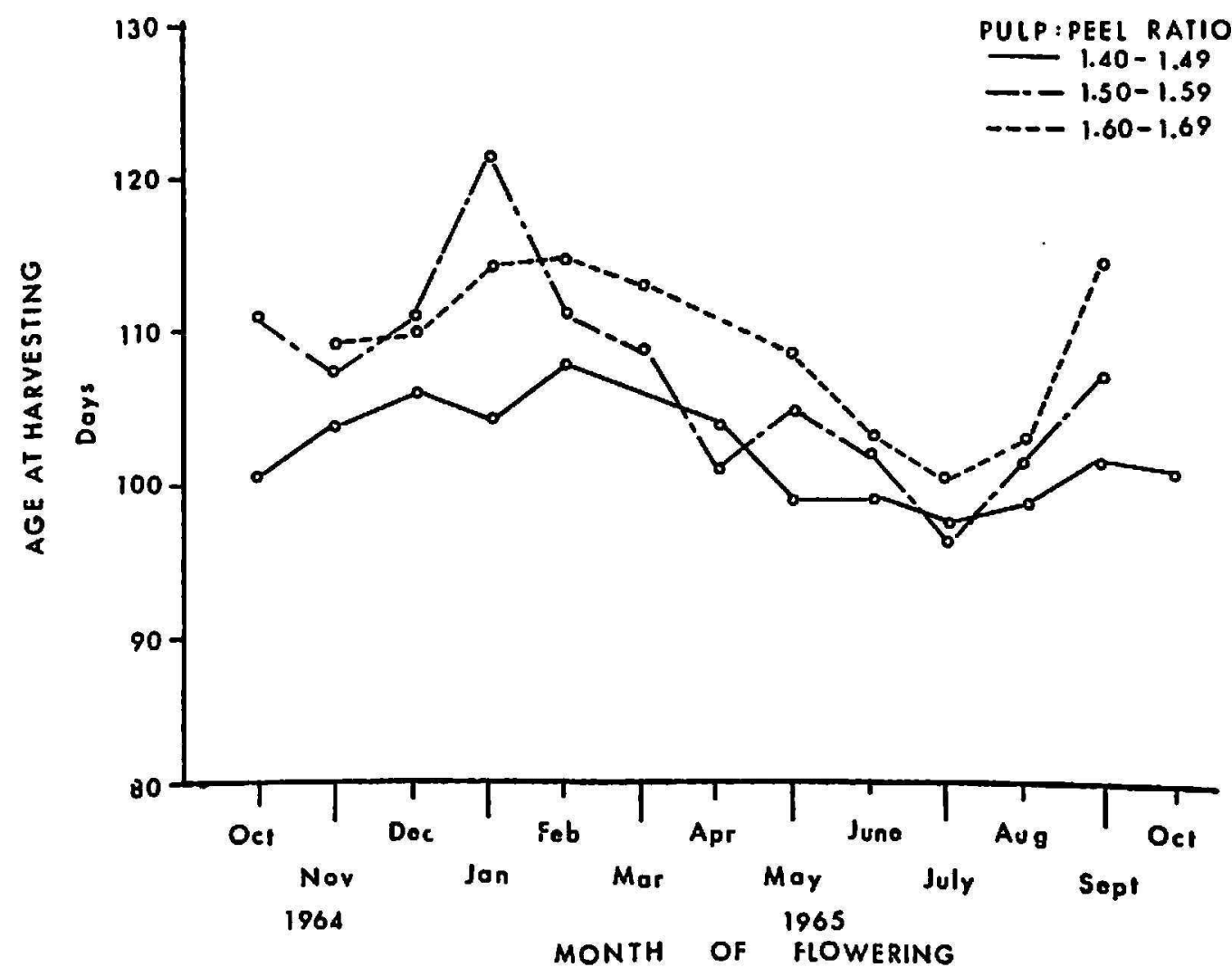

Fra. 10.-Variation in age with the month of flowering for bunches with pulp:peel ratio of $1.40-1.49,1.50-1.59$, and $1.60-1.69$. 
of development, the age of the fruit increased reaching a maximum in January to decrease steadily to reach a minimum in July, and to increase again from August on. Fruit harvested from plants blooming during January had an average age at harvesting of 122 days, while fruit harvested from plants blooming during July had an average age of 96 days. At both points, the fruit was at a stage of development corresponding to "full three-quarter".

The data from these experiments suggest that, in order to harvest fruit at a certain stage of development, the age at harvesting must vary throughout the year. From a practical point of view, it is desirable to establish the best age range for harvesting the fruit, so that variations in quality are minimized. In Puerto Rico, where bananas are sold only in local markets, and where the distance from farms to ripening plants is no more than 100 miles, it may be possible to harvest the fruit at a fairly advanced stage of development. If this is possible, higher yields would be obtained by farmers.

Bunches were harvested at a stage of development ranging from "threequarters" to "full" and ripened under controlled conditions as described under Experimental Procedures. The results of these experiments showed that the fruit harvested "light-full three-quarters" to "full-ripened" was satisfactory. Fruit at the "three-quarter" stage was considered too underdeveloped for the local market, and often showed uneven ripening behavior. Fruit at the "full" stage was difficult to handle and, during ripening, fingerdrop and peel-splitting sometimes occurred. For the local market, fruit at a stage of development corresponding to upper "light-full three-quarter" to "full three-quarter" seems to be the most appropiate. Harvesting at this stage offers the added advantage of minimizing the effect of time of planting or shooting on the stage of development at harvesting. The curves in figure 9 show that at the lower stages of development (lower values for the pulp:peel ratio) there is less variation in age with the time of shooting. The fruit harvested at a pulp: peel ratio of 1.40-1.49 throughout the year ranged in age from 98 to 108 days. Thus fruit harvested at an age around 100 days would be fairly uniform throughout the year.

Table 4 shows the starch and reducing sugar content of ripened fruit harvested throughout the year from the 12 plots at an age ranging from 96 to 106 days. The fruit was ripened at $68^{\circ} \mathrm{F}$. for 5 days, at the end of which all lots had ripened to color 4-5. The starch and reducing sugar values show that the fruit ripened to nearly the same stage throughout the year. The fruit always ripened evenly, with green tip at color stage 4-5, with a bright-yellow color. Organoleptic evaluation showed that the fruit was of very high quality. Quality was maintained throughout the year, irrespective of the month at which the fruit was harvested. 
BANANA GROWTH ON THE SOUTH COAST OF PUERTO RICO.

TABLE 4.-Reducing sugars and starch content of bananas ripened to color 4-5 at $68^{\circ} \mathrm{F}$

\begin{tabular}{c|c|c|c}
\hline Plot No. & Age at harvestings & Reducing sugars & Starch \\
\hline & Days & Percent & Percent \\
1 & 97 & 6.43 & 3.21 \\
2 & 97 & 7.28 & 2.26 \\
3 & 96 & 7.28 & 3.83 \\
4 & 106 & 11.54 & 2.73 \\
5 & 100 & 7.72 & 1.28 \\
6 & 107 & 7.79 & 1.24 \\
7 & 98 & 6.33 & 1.07 \\
8 & 100 & 5.62 & 1.34 \\
9 & 102 & 5.15 & 3.21 \\
10 & 96 & 5.36 & 1.14 \\
11 & 96 & 6.50 & 2.25 \\
12 & 103 & 7.40 & 2.21 \\
\hline
\end{tabular}

1 After shooting.

TABLE 5.-Characteristics of the fruit produced by plants flowering during a calendar month

\begin{tabular}{|c|c|c|c|c|c|}
\hline Month of flowering & $\begin{array}{c}\text { Age atl } \\
\text { harvesting }\end{array}$ & $\begin{array}{c}\text { Average weight } \\
\text { of bunch }\end{array}$ & $\begin{array}{l}\text { Average weight } \\
\text { of fingers }\end{array}$ & Pulp:peel ratio & $\begin{array}{l}\text { Fruits per } \\
\text { bunch }\end{array}$ \\
\hline - & Days & Pounds & Grams & & Number \\
\hline 1984 & & & & & \\
\hline October & 103.1 & 26.0 & 107.2 & 1.29 & 98 \\
\hline November & 103.1 & 28.8 & 129.4 & 1.46 & 99 \\
\hline December & 107.6 & 36.3 & 141.5 & 1.40 & 120 \\
\hline Thury & 1083 & 37.7 & 148.5 & 140 & 114 \\
\hline Jancis & 100 & 37.2 & 1611 & 144 & 100 \\
\hline February & 100.0 & & & & 100 \\
\hline March & 109.3 & 40.4 & 164.4 & 1.54 & 109 \\
\hline April & 102.4 & 37.7 & 166.7 & 1.49 & 105 \\
\hline May & 103.8 & 35.9 & 149.6 & 1.41 & 106 \\
\hline June & 101.9 & 39.4 & 174.7 & 1.57 & 101 \\
\hline July & 97.9 & 47.7 & 178.9 & 1.54 & 123 \\
\hline August & 100.2 & 44.0 & 172.5 & 1.50 & 117 \\
\hline September & 102.7 & 27.0 & 144.9 & 1.46 & 115 \\
\hline October & 100.7 & 26.8 & 103.6 & 1.31 & 110 \\
\hline
\end{tabular}

1 After shooting.

\section{THE EFFECT OF TIME OF SHOOTING ON YIELDS}

To determine yields, the bunches were harvested at similar stages of development between "light-full three-quarter" and "full three-quarter". The age at harvesting, pulp:peel ratio, weight of the bunches and fingers, and the number of fruit per bunch for fruit harvested from plants flowering within a calendar month, are given in table 5 . When the average weight 
of the bunches, the weight of the fingers and the number of fruit per bunch are plotted against the month of shooting the curves shown in figure 10 were obtained.

The average weight of the bunches increased steadily from October to
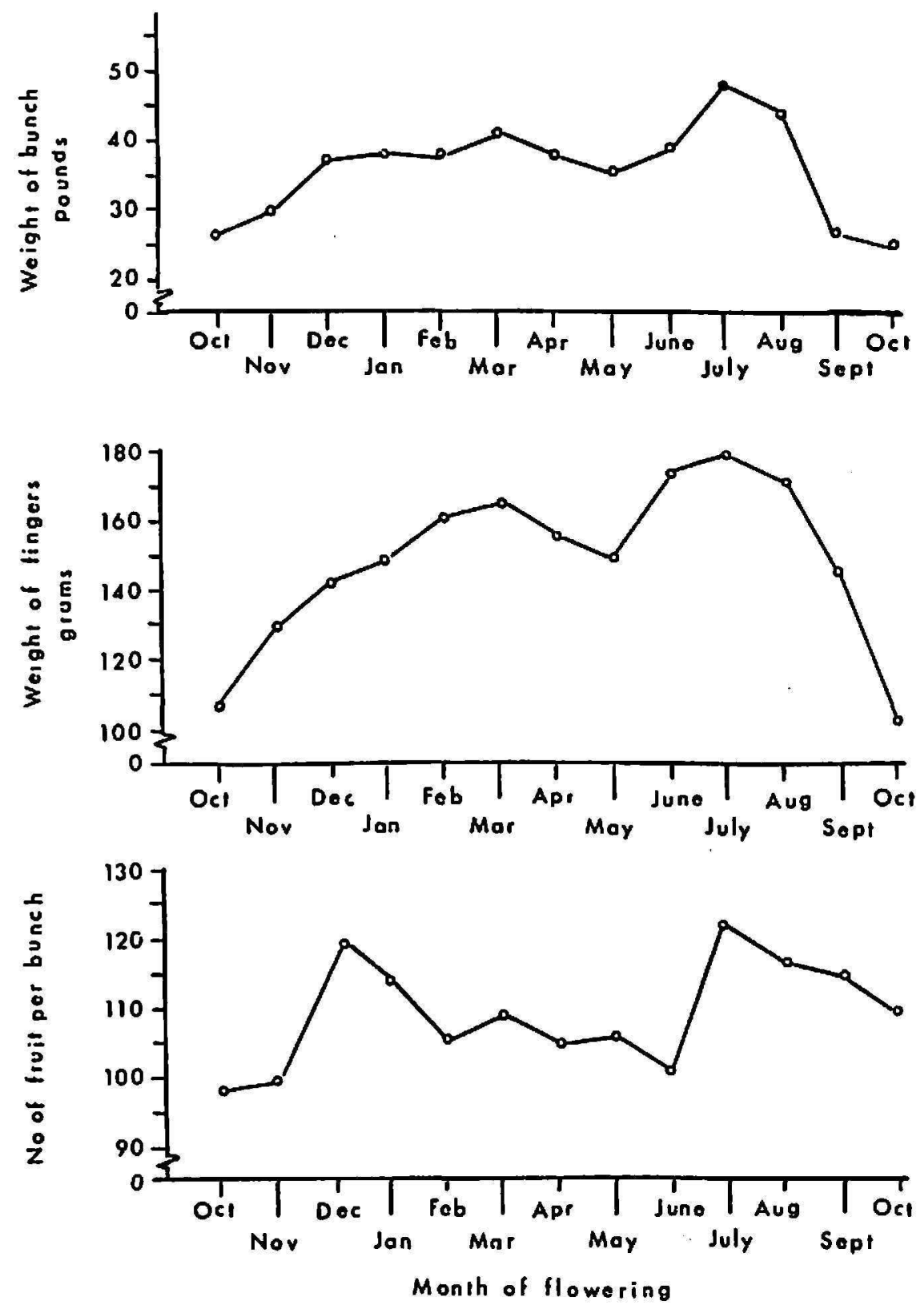

Fre. 11.-Variation of the weight of the bunch, the weight of the fruit, and the number of fruits per bunch with the month of flowering.

March, decreased from March to May, increased again reaching a maximum in July and decreased again reaching a minimum in October. The shape of this curve indicates a definite relationship to the time of shooting with the weight of the bunches. If the overall shape of the curve is considered, disregarding monthly variation, it is seen that the weight of the bunches in- 
creased steadily from October to July and then decreased to reach a value similar to that obtained in October a year before. This same trend was observed in a previous experiment in plots harvested from August 1962 to October 1963.

A similar pattern of variation is observed in the average weight of the fingers (fig. 11).

The average number of fingers per bunch changed in a cyclic way during the year, and does not follow the same pattern of variation with the month of flowering as did the weights of the bunches and fingers (fig. 11).

When all bunches harvested from plants blooming within a calendar month are combined into three groups according to their weights, the data shown in table 6 are obtained. Plotting the data for the groups with the minimum and maximum weights against the month of inflorescence results in the curves in figure 12. The percentage of bunches weighing less than 35.1 pounds decreased steadily from October to July, to increase again in August. The percentage of bunches weighing more than 40 pounds increased steadily to July and decreased in August. The percentage of bunches weighing from 35.1 to $\mathbf{4 0 . 0}$ pounds showed much less variation with the time of shooting.

\section{CHARACTERISTICS OF THE FRUIT HARVESTED}

The variations in yields and quality attributes of the fruit as related to the time of shooting has already been discussed. Since this study lasted for over a year, it seems pertinent to consider the overall quality of the fruit produced during the period.

Although the average weight of the bunches was found to vary with the time of shooting, the weights of the bunches harvested from plants flowering within a calendar month varied within wide limits. However, when all bunches harvested from the 12 plots are grouped according to their weights, the frequency distribution curve has a shape similar to that of a normal distribution. In the tabulation which follows, the percentage distribution of the bunches harvested grouped by their weights is given. This distribution is based on 511 bunches harvested throughout the year.

$\begin{array}{cr}\text { Weight range in poutds } & \text { Percent } \\ <20.0 & 5.5 \\ 20.1-25.0 & 9.0 \\ 25.1-30.0 & 15.0 \\ 30.1-35.0 & 16.0 \\ 35.1-40.0 & 18.5 \\ 40.1-45.0 & 11.0 \\ 45.1-50.0 & 10.5 \\ 50.1-55.0 & 6.0 \\ 55.1-60.0 & 4.5 \\ 60.1-65.0 & 4.0\end{array}$


Approximately 70 percent of the bunches harvested weighed from 25 to 50 pounds.

From the standpoint of the weight and number of fruits per hand, the bunches are fairly uniform. Table 7 shows the weight of the different hands and the number of fruits per hand, from bunches of the weight ranges indicated.

TABLE 6.-Percenlage of bunches weighing from less than 20.0 to 55.0 ;

s5.1 to 40.0; and from 40.1 to 65.0 pounds, harvested from plants flowering wilhin a calendar month.

\begin{tabular}{l|c|c|c}
\hline \multirow{2}{*}{ Month of fowering } & \multicolumn{2}{|c}{ Percentage of bunches within weight range indicated } \\
\cline { 2 - 4 } & $20.0-35.0$ & $35.1-40.0$ & $40.1-65.0$ \\
\hline 1964 & & & \\
October & 83.3 & 16.7 & - \\
November & 75.0 & 17.2 & 7.8 \\
December & 45.0 & 18.3 & 36.7 \\
1965 & & & \\
January & 52.2 & 26.0 & 21.8 \\
February & 43.4 & 43.3 & 13.3 \\
March & 50.1 & 14.3 & 35.6 \\
April & 36.9 & 36.8 & 26.3 \\
May & 58.5 & 4.9 & 36.6 \\
June & 36.2 & 16.6 & 47.2 \\
July & 5.6 & 17.2 & 77.2 \\
August & 18.7 & 18.8 & 62.5 \\
September & 42.0 & 16.0 & 42.0 \\
October & 06.2 & - & 3.8 \\
\hline
\end{tabular}

In the tabulation which follows, the percentage of bunches with the number of hands indicated are given. About half of the bunches harvested had 7 hands, 42 percent had 6 and 8 hands, and only about 3 percent had 9 hands.

$\begin{array}{cc}\text { Number of hands } & \text { Percent bunches } \\ 6 & 17.1 \\ 7 & 54.9 \\ 8 & 25.2 \\ 9 & 2.8\end{array}$

From the standpoint of export fruit, the bananas harvested are of low grade mainly due to the high percentage of bunches with 7 hands. However, for the local market or for processing the fruit was considered to be very good.

In the previous tables the characteristics of the fruit harvested were 
arranged by the month in which shooting occurred. The data have been rearranged to group the fruit by the month in which it was harvested. The rearranged data are shown in table $S$. The highest yields and fruit of the best quality from the standpoint of fruit size and weight, were harvested during the autumn. This can be attributed to the fact that during the month preceding fruit set, the most favorable weather conditions prevailed,

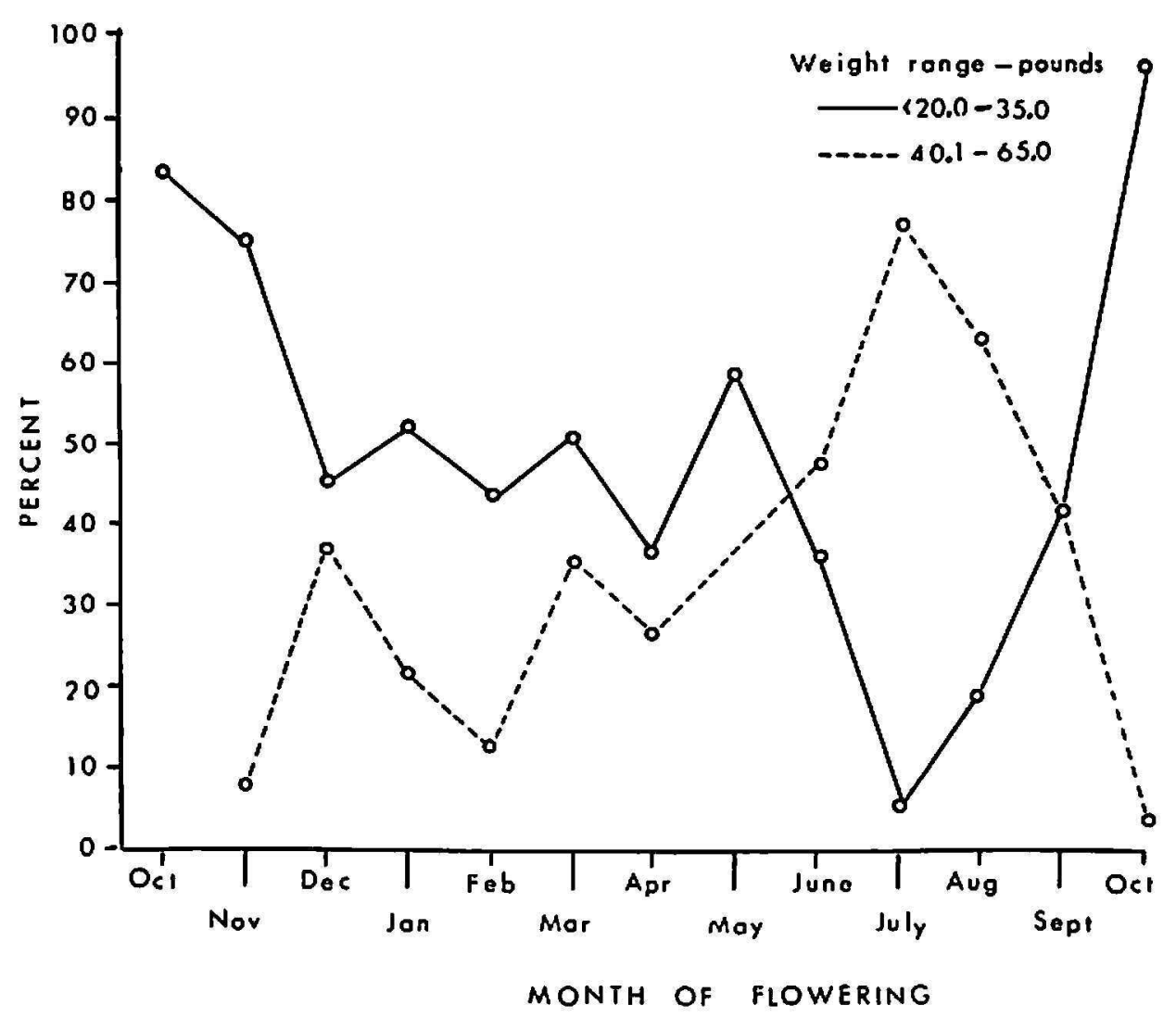

FIG. 12.-Percentage of bunches weighing from less than 20.0 to 35.0 pounds and from 40.0 to 65.0 pounds produced from plants flowering monthly from October 1964 to Oetober 1965.

with an average temperature above $80^{\circ} \mathrm{F}$., which according to Simmonds (4) is satisfactory for banana production.

\section{SUMMARY}

Twelve monthly plots of the Montecristo cultivar were established at the lortuna Substation on the Southern Coast of Puerto Rico. The time of planting was found to affect the interval from planting to shooting, resulting in a grouping of the plots into 6 periods of flowering. The length of the flowering period for all 12 plots ranged from 102 to 147 days. Bunches could be harrested continuously throughout the year.

The time of shooting had a direct effect on the derelopment of the bunch. The time required for the bunches to reach a definite stage of development 
TABLE 7.-Weight of hands in pounds $(A)$ and number of fruits per hand (B) for bunches harvested, grouped according to their weights in pounds as indicated

\begin{tabular}{|c|c|c|c|c|c|c|c|c|c|c|c|c|c|c|}
\hline \multirow{3}{*}{ Hand No. } & \multicolumn{14}{|c|}{ Weight ranges of bunches } \\
\hline & \multicolumn{2}{|c|}{$20.0-25.0$} & \multicolumn{2}{|c|}{$25.1-30.0$} & \multicolumn{2}{|c|}{$30.1-35.0$} & \multicolumn{2}{|c|}{$35.1-10.0$} & \multicolumn{2}{|c|}{$40.1-45.0$} & \multicolumn{2}{|c|}{$45.1-0.0$} & \multicolumn{2}{|c|}{50.0} \\
\hline & $A$ & B & $A$ & $\mathbf{B}$ & $A$ & B & A & $\mathbf{B}$ & $A$ & $\mathbf{B}$ & A & B & $A$ & B \\
\hline 1 & $\mathbf{3 . 5}$ & 12 & 5.5 & 18 & 6.5 & 19 & 6.8 & 22 & 7.3 & 19 & 7.4 & 19 & 9.6 & 22 \\
\hline 2 & 4.9 & 17 & 4.2 & 16 & 6.5 & 15 & 5.5 & 17 & 5.5 & 15 & 7.9 & 20 & 7.4 & 18 \\
\hline 3 & 3.2 & 12 & 3.8 & 14 & 4.8 & 15 & 6.1 & 18 & 5.1 & 15 & 7.0 & 17 & 6.9 & 16 \\
\hline 4 & 3.2 & 12 & 3.6 & 15 & 4.5 & 14 & 4.8 & 15 & 4.5 & 14 & 5.9 & 16 & 6.3 & 16 \\
\hline 5 & 3.3 & 13 & 3.3 & 14 & 4.1 & 14 & 4.6 & 15 & 4.2 & 14 & 5.5 & 15 & 5.5 & 15 \\
\hline 6 & 2.8 & 13 & 3.1 & 13 & 3.6 & 14 & 4.0 & 14 & 3.8 & 14 & 5.1 & 15 & 5.1 & 15 \\
\hline 7 & 2.4 & 12 & 2.5 & 13 & 3.1 & 13 & 3.4 & 13 & 3.1 & 12 & 4.5 & 14 & 4.6 & 14 \\
\hline 8 & - & - & - & $\longrightarrow$ & $\rightarrow$ & - & 3.2 & 13 & - & - & 4.2 & 14 & 3.9 & 14 \\
\hline
\end{tabular}

TABLE 8.-Characteristics of the fruit harvested at the month indicated

\begin{tabular}{|c|c|c|c|c|c|}
\hline Month harvested & Age at barvesting & $\begin{array}{c}\text { Average weight } \\
\text { of bunch }\end{array}$ & $\begin{array}{l}\text { Average fruit } \\
\text { per bunch }\end{array}$ & $\begin{array}{c}\text { Average weight } \\
\text { of fruit }\end{array}$ & Pulp:peel ratio \\
\hline & Days & Pounds & Xumber & Grams & \\
\hline 1965 & & & & & \\
\hline January & 101.8 & 28.0 & 94 & 125.0 & 1.28 \\
\hline February & 99.7 & 25.3 & 96 & 114.5 & 1.35 \\
\hline March & 105.6 & 32.6 & 105 & 139.6 & 1.48 \\
\hline April & 106.1 & 37.7 & 113 & 145.5 & 1.44 \\
\hline May & 104.4 & 38.0 & 99 & 170.5 & 1.45 \\
\hline June & 110.2 & 38.0 & 103 & 157.9 & 1.52 \\
\hline July & 105.6 & 37.5 & 107 & 156.0 & 1.49 \\
\hline August & 100.6 & 39.8 & 122 & 163.9 & 1.63 \\
\hline September & 104.8 & 40.1 & 105 & 166.4 & 1.45 \\
\hline October & 96.8 & 44.7 & 117 & 174.8 & 1.58 \\
\hline November & 101.6 & 46.1 & 119 & 177.2 & 1.56 \\
\hline $\begin{array}{l}\text { December } \\
1966\end{array}$ & 100.0 & 35.1 & 109 & 144.2 & 1.37 \\
\hline January & 103.9 & 19.4 & 111 & 113.4 & 1.37 \\
\hline
\end{tabular}

decreased from the flowering of October to that of July of the following year, to increase again from August to October.

Changes in the weight of the fingers, pulp content, and in the values of the pulp:peel ratios were studied by harvesting fingers from a number of bunches which were left on the tree until incipient ripeness. A continuous increase in all three attributes were observed during the development period. The changes in carbohydrates, acidity and $\mathrm{pH}$, and moisture were determined during the development period. 
The time of flowering had a direct effect on the yields. Both the weight of the bunches and of the fingers harvested from plants blooming from October to August of the following year increased, reaching a maximum in July, to decrease again reaching a minimum in October. The number of fingers per bunch varied in a cyclic way throughout the year.

The weight of the bunches harvested from all plots ranged from less than 20 to more than 60 pounds. The highest percentage of bunches harvested weighed between 35 and 40 pounds. The number of hands per bunch ranged from 6 to 9 , with the highest percentage of bunches having 7 hands.

The fruit harvested from all 12 plots was of good quality, ripening evenly to a bright-yellow color.

\section{RESUMEN}

Se llevó a cabo un estudio para determinar cómo se comporta el guineo Montecristo cuando se siembra mensualmente durante un año. Estas siembras experimentales se establecieron en la Subestación de Fortuna en la Costa Sur de Puerto Rico, al nivel del mar y sin sombra.

La época de siembra tuvo un efecto directo sobre el intervalo de tiempo que transcurrió entre la siembra $y$ la florecida. Varias siembras florecieron casi a la vez, lo que resultó en la agrupación de las siembras en 6 periodos de florecida. Los periodos de las florecidas de las siembras se extendieron de 102 a 147 días. Debido a lo extenso de los periodos de las florecidas, se produjo fruto todo el año.

Se estudió cómo varián el peso de la fruta, el contenido de pulpa y la cáscara y la razón de pulpa a cáscara durante el desarrollo del racimo. Para estos estudios, se dejó el racino en la mata y se removieron las frutas para análisis, a intervalos frecuentes. También se estudiaron la variación en el contenido de azúcares y almidón, en el $\mathrm{pH}$ y la acidez, y en la humedad de la pulpa de la fruta. El peso de la fruta, el contenido de pulpa y los valores para la razón de pulpa a cáscara aumentaron en forma casi linear durante el periodo de desarrollo del racimo.

La época de la florecida tuvo un efecto marcado sobre el desarrollo del racimo y de la fruta. El tiempo necesario para el desarrollo del racimo hasta un grado determinado, disminuyó desde la florecida de octubre hasta la de julio del próximo año, para luego aumentar desde agosto hasta el próximo octubre.

La época de la florecida tuvo también un efecto directo sobre el peso del racimo y de la fruta. El peso de la fruta y del racimo aumentó progresivamente desde la florecida de octubre hasta la de julio del próximo año, para luego disminuir hasta llegar a un mínimo durante el siguiente mes de octubre.

El peso de los racimos cosechados en el experimento fluctuó entre menos 
de 20 libras y más de 60 . El porcentaje major de los racimos cosechados registró un peso que fluctuó entre 35 y 40 libras. El número de manos por racimo varió entre 6 y 9 , pero el mayor procentaje de los racimos cosechados tenía 7 manos.

La fruta que se cosechó durante todo el año fue de muy buena calidad y maduró satisfactoriamente bajo condiciones controladas de temperatura y humedad relativa y con la aplicación de etileno. La fruta maduró uniformemente y su color fue un amarillo brillante muy atractivo.

\section{LITERA'TURE CITED}

1. Fervegant, D., Bananier et son Exploitation, Societé D'Editions Geographique' Maritimcs et Coloniales, Paris, France, 578 pp., 1935.

2. Von Loesecke, H. W., Banana, New York Interscience Publishers, New York, N. Y., 189 pp., 1949.

3. Cardeñosa Barriga, R., El Género Musa en Colombia, Pub. Téenica, Est. Agr. Expt., Ministerio de Agricultura y Ganadería, Palmira, Colombia, 383 pp., 1954.

4. Simmonds, N. W., Bananas, Longmans, Green and Co., Ltd., London, England, 466 pp., 1960.

5. Champion, J., Le Bananier, G. P. Maisonneuve and Larose, Paris, France, 263 pp., 1963.

6. Banana Ripening Manual, Fruit Dispatch Co., Boston, Mass., 32 pp., 1961.

7. Wardlaw, C. W., Leonard, E. R., and Barnell, H. R., Metabolic and storage investigations on the banana, Low Temp. Res. Sta., Imp. College of Trop. Agr., Trinidad, Memoir 11: 3-8, 1939.

8. González Ríos, P., Bol. Ins. Agr. Expt. Sta., Dept. of Agr. and Labor, Río Piedras, P.R., 36-58 pp.

9. Vicente-Chandler, J., Abruna, F., and Silva, S., Effect of shade trees on yields of five crops in the Mountainous Region of Puerto Rico, J. Agr. Univ. P.R. 50 (3): 218-25, 1966.

10. Calpouzos, L., Colberg, C., Riollano, A., Ramos, C., and Theis, T., The control of Sigatoka disease of bananas by oil spray schedules based on rainfall data, J. Agr. Univ. P.R. 48 (1): 32-8, 1964.

11. Carter, G. H. and Neubert, A. M., Rapid determination of starch in apples, J. Agr. Food Chem. 2 (21): 1070-72, 1954.

12. Moyer, J. C. and Holgate, K. C., Determination of aleohol-insoluble solids and sugar content of vegetables, A nal. Chem. 20 (5): 472-74, 1948.

13. Methods of Analyses of the Association of Official Agricultural Chemists, 9th ed., Washington, 1). C., 1960. 